\title{
Increasing on-farm resilience to adverse weather events: a Northland case study
}

\author{
T. D. WHITE ${ }^{1}$, H.G. MOODIE ${ }^{2}$ T.A. PAYNE ${ }^{1}$, M.E. WEDDERBURN ${ }^{1}$ and N. BOTHA ${ }^{1}$ \\ ${ }^{1}$ AgResearch, Ruakura Research Centre, Hamilton \\ ${ }^{2}$ NZ Landcare Trust, Whangarei \\ toni.white@agresearch.co.nz
}

\begin{abstract}
The results of a study investigating the response of farmers to adverse weather events are outlined. The aim was to identify adaptive management activities that would increase on-farm resilience. This project focused on beef/sheep farmers, dairy farmers and horticulturalists in Northland. Participants were pragmatic about adverse weather events, particularly storms. Local knowledge, previous experiences, information and networks helped build resilience. Participants highlighted a range of tactical decisions to address immediate damage from storms. However, strategic planning and adaption varied amongst farmers and orchardists as assessment of the cost-benefit of strategic actions differed. This information can be used to help farmers and organisations that assist with recovery assess and build resilience to adverse weather events.
\end{abstract}

Keywords: Northland, dairy, beef/sheep, orchardist, resilience

\section{Introduction}

Consider this... you are a farmer or horticulturalist busy on farm/orchard with the day to day chores of working the land, when the low intensity early winter storm you were expecting instead turns into a event so large it is considered a 'one in a hundred year storm'. The soil is slipping on the hills, the flats are flooded and you are hoping to still have the same amount of stock/crop that you had yesterday. Imagine recovering from this storm only to be hit by another 2 months later. How prepared are you?

This is not an imaginary scenario. This is the situation in which Northland agriculturalists found themselves in 2007. A low pressure system veered across the Tasman and hit Northland in March with more than $400 \mathrm{~mm}$ of rain over 8-10 h (NIWA 2007). Extensive flooding and erosion occurred on-farm and communities struggled. Following the storm, farmers and communities went into recovery mode cleaning up after the storms trail of destruction. Two months later farmers were hit by a similar storm. There was over $200 \mathrm{~mm}$ of rain over 2 days with winds gusting in excess of $180 \mathrm{~km} / \mathrm{h}$ in some areas. Again the damage levels were high. These two storms were estimated to cost dairy farmers in the
Hikurangi Swamp \$15 million (Dinsdale 2007), while avocado growers in Whangarei reported an estimated $\$ 40$ million in lost production (NZ Herald 2007).

With such damage and large costs of recovery, the question was asked: "how resilient are Northland farmers to adverse weather events?" Resilience in social ecological systems such as farms and orchards is identified as "the capacity of a system to absorb disturbance and reorganise while undergoing change so as to still retain essentially the same functions, structure, identity and feedbacks" (Walker et al. 2004). Two important components of resilience are a farmer's perceptions of possible risk and their adaptive capacity (the ability and desire to respond to a perceived risk). This paper highlights the results of a study designed to identify the practices farmers undertake to prepare for and recover from adverse weather events in Northland.

\section{Methods}

The livestock farming community was broken down into two subgroups: dairy and sheep and beef farmers. Northland has $8.1 \%$ of the nation's dairy herds covering an area of 118,660 effective hectares and average herd sizes of 285 cows (LIC 2008); while Northland represents $11 \%$ of the national beef herd and $1.3 \%$ of the national sheep flock (Statistics NZ 2007). The horticultural sector is more diverse in nature. The avocado industry was selected as a case study as it is the second largest horticultural land user in Northland (1325 ha) (MAF 2008), and avocado growers were heavily impacted by the 2007 storms.

Three focus groups (Table 1) were held with each of the three sectors to provide a foundation for designing a semi-structured qualitative interview process. Ten semi-structured interviews were then undertaken in each of the three sectors across Northland. Farmers were asked questions based around five main themes: farm demographics (Table 2); historic storm experience; impact of the 2007 storms; response to the 2007 storms; information sources that were useful. Notes were taken during interviews and copies supplied to participants. Once collected these qualitative data was analysed to reduce the information to a descriptive form (Greene 2007) from which key themes of resilience were 
Table 1 Participant numbers in study.

\begin{tabular}{llll}
\hline Sector type & Dairy & Beef/sheep & Horticulture (Avocado) \\
\hline Focus Groups & 6 & 5 & 4 \\
Interviews & 10 & 10 & 10 \\
\hline
\end{tabular}

Table 2 Demographics of participants in Northland.

\begin{tabular}{|c|c|c|c|c|}
\hline Sector & Measurement & Property size (ha) & Stock/tree numbers & $\begin{array}{c}\text { Years on current } \\
\text { property }\end{array}$ \\
\hline \multirow[t]{3}{*}{ Dairy } & Average & 413 & 372 & 26 \\
\hline & Maximum & 1052 & 1050 & 68 \\
\hline & Minimum & 100 & 205 & 2 \\
\hline \multirow[t]{3}{*}{ Beef/sheep } & Average & 241 & 1092 & 25 \\
\hline & Maximum & 485 & 5000 & 50 \\
\hline & Minimum & 22 & 120 & 8 \\
\hline \multirow[t]{3}{*}{ Avocado } & Average & 16 & 2087 & 19 \\
\hline & Maximum & 65 & 8000 & 45 \\
\hline & Minimum & 3 & 600 & 3 \\
\hline
\end{tabular}

identified as well as the strategies farmers/orchardists were undertaking to build resilience to adverse weather events.

The aim of this study was not to statistically analyse levels of resilience in Northland agriculture but to build a picture of factors that were influencing farmer/horticulturalist resilience and to use this knowledge in following years to assist farmers and organisations involved in aiding rural recovery from adverse weather events.

\section{Results and Discussion}

\section{Storm impact}

The impact of the storms on farms and orchards in Northland varied between sectors and locations. More than half of the fruit on avocado trees fell to the ground during the storms while the rest was downgraded in quality. All orchards experienced tree damage with at least $10-15 \%$ of mature trees toppled, thus having an effect on future production. Interviews with growers revealed that the emotional toll of the storms was high, with orchard losses ranging from $\$ 15-\$ 900 \mathrm{~K}$.

The tendency for dairy farms to be located on flatter land, often near waterways, meant that heavy rain led to considerable flooding. Flooding created access issues for farmers trying to get cows to milking sheds. This was confounded by the loss of electricity restricting milking operations. Paddocks underwater also restricted the amount of feed available to stock. While no study participants lost stock, costs were incurred through repairing fencing and pastures, grazing stock off farm, and accessing milking facilities.

Storm impacts on beef/sheep farms participating in the study were similar to dairying where farm flats were flooded. Fences and pasture were damaged, but no stock was lost. The steeper topography often associated with dry stock farming provided advantages as stock could be kept on hillsides. However, the effect of erosion was greatest on beef/sheep farms due to the slope of the land and the weight of rain-loaded soils. Interviews with these farmers indicated costs of recovery ranged from $\$ 10-\$ 150 \mathrm{~K}$ if all infrastructural repair costs were accounted for.

\section{Storm expectancy}

Adverse weather events were identified as a hazard that occurred when working with natural systems. Farmers and orchardists indicated that they expect a storm event to occur regularly although the frequency of significant storm events was unpredictable. Many participants held knowledge of past storms through the development of a social memory based on historic experiences (their own, family or community members) or from networks within a particular locality.

\section{Preparedness and reactions}

All participants identified the difficulty of predicting and planning for all possible adverse weather events. Evaluation of the perceived threat posed by an event allowed the farmer to assess the level of activity or action needed to reduce their perceived risk. This focus 
Table 3

Examples of activities undertaken by farmers/orchardists in the study.

\begin{tabular}{|c|c|c|}
\hline & Horticulture & Beef/sheep and Dairy \\
\hline Tactical: Before storm & Checking/clearing drains & Moving stock \\
\hline Tactical: After storm & $\begin{array}{l}\text { Clear fallen trees to allow access } \\
\text { Remove fruit from under trees } \\
\text { to discourage sprouting } \\
\text { Spray for Phytothera } \\
\text { Contact industry or aid based organisations } \\
\text { for assistance e.g. Taskforce Green }\end{array}$ & $\begin{array}{l}\text { Check on stock and secure } \\
\text { Re-establish fencing and pastures } \\
\text { Secure stock feed } \\
\text { Contact industry or aid based organisations for assis- } \\
\text { tance e.g. Taskforce Green or DairyNZ } \\
\text { Secure ability to milk } \\
\text { Clear farm tracks for access }\end{array}$ \\
\hline $\begin{array}{l}\text { Strategic: readiness for } \\
\text { a storm }\end{array}$ & $\begin{array}{l}\text { Increase height of shelterbelts } \\
\text { Decrease crop height } \\
\text { Increase drainage } \\
\text { Income diversification } \\
\text { Seek more information about preparedness } \\
\text { for adverse events } \\
\text { Follow weather forecasts } \\
\text { Utilise existing mitigation tools e.g. irrigation }\end{array}$ & $\begin{array}{l}\text { Feed strategy: store or have access to sufficient feed } \\
\text { Stocking strategy to ensure flexibility to fit farm limita- } \\
\text { tions } \\
\text { Secure water supplies to stock } \\
\text { Adapt system such as utilising two wire electric fences } \\
\text { in flood areas, generators, standoff pads etc } \\
\text { Income diversification } \\
\text { Establish a plan for working with and adapting to the } \\
\text { farm's limitations e.g. erosion control plan } \\
\text { Strategically use farm flats } \\
\text { Cut down dangerous trees } \\
\text { Plant trees to reduce erosion } \\
\text { Keep waterways clear of weeds } \\
\text { Follow weather forecasts } \\
\text { Participate in local information networks e.g. ringing to } \\
\text { inform other people in an area of danger }\end{array}$ \\
\hline
\end{tabular}

was individual and farm specific. From the interviews it was evident that the experience participants had in farming and orcharding, and on a specific farm, orchard or region was important when assessing the risk and deciding on the appropriate action.

Adaptive capacity is the ability of a system to make changes that result in increased resilience (Walker et al. 2004). Participants who had increased the flexibility of their management systems and prepared a range of measures to counter effects of a significant storm had a greater ability to recover quickly from an adverse storm event. These participants were more informed about how to respond and deal with the consequences of such an event. Farmer knowledge and efficacy were therefore highlighted as important factors in risk management and therefore resilience in this study.

Participants discussed a range of responses to the storm events they had experienced (Table 3). For the horticultural group, there was a general view that little can be done immediately before a storm event. Dairy and beef/sheep farmers, however, highlighted the need to check and ensure stock were safe and secure. Most activity was in the recovery stage after the storm had passed. This ranged from removing damaged or fallen trees and fruit for growers to re-establishing fencing, pastures, and feed security for dry stock for dairy farmers.

In general, the types of actions described by participants were either strategic or tactical. Strategic actions are those made over a longer-term, typically $1-5$ years (Risbey et al. 1999) and refer to more structural changes on farm as a result of farm management decisions. Tactical responses are those made over the short-term e.g. within a particular season (Smit \& Skinner 2002). Importantly, the evaluation of costs versus benefits was a recurring theme when deciding on actions to be undertaken.

For horticulturalists, many of the strategic activities were seen as 'best practice' in terms of orchard management and included activities such as shelter heights and reducing tree crop height. Dairy, beef and sheep farmers had a mix of tactical and strategic practices. This included such actions as using one or two wire fencing, managing feed surplus storage and keeping relevant equipment and some stores on-farm. All groups highlighted a time-lag effect involved in recovery from weather events. Strategies for immediate recovery versus long-term recovery differed. In horticulture it was noted that fruit may not show damage until after harvest, while in livestock farming, damaged pastures could take some time to recover and come back into the grazing rotation with some dairy farmers loosing between $20-40 \%$ of their farm production area after flooding. The cost of becoming operational again (as noted previously) was high for all groups.

After the recent 2007 storm events, only a small number of participants (predominantly dairying) had invested heavily in strategic activities. This included purchasing and setting up generators for cowsheds. These participants had considerable assets to protect 
and were financially able to invest further in risk mitigation. The majority of other participants had weighed up the cost versus benefit and decided against large investment; instead concentrating on other onfarm strategic activities such as maximising production opportunities while they were available. These farmers believed adverse weather events did not occur frequently enough to offset the costs of investment.

\section{Conclusions}

Farmers from three sectors: dairying, horticulture and beef and sheep, provided an insight into the effect of, and some of the issues associated with adverse weather events in Northland. The results of this study highlighted a range of tactical and strategic activities to address adverse weather events. Key findings identified from the study include:

Farmers vary in their perception of adverse weather events - in terms of whether or not an event is likely to happen, the expected damage that will occur and therefore the level of their willingness to spend money on adaptation and risk mitigation.

The importance of connecting with local and industry networks. These are often the source of considerable knowledge and assistance.

Balancing the social, economic and biophysical factors to find adaptions best suited to a particular farm or orchard business.

Identifying a range tactical decisions and actions for immediate recovery after the event.

\section{ACKNOWLEDGEMENTS}

The authors wish to thank all the farmers who gave up their time to participate in the focus groups and interviews; and the project team for the Northland Farm Resilience Project for their input and direction. The project was funded by MAF SFF and the Northland Regional Council.

\section{REFERENCES}

Dinsdale, M. 2007. Storm bills nudge $\$ 100 \mathrm{~m}$. In: The Northern Advocate (20/08/2007), Whangarei.

Greene, J.C. 2007. Mixed methods in social inquiry. Jossey-Bass, San Francisco. 216 pp.

LIC. 2008. New Zealand dairy statistics 2007-08. pp. 1-48. Livestock Improvement Corporation, Hamilton.

MAF. 2008. Horticulture and arable monitoring report. Report Ministry of Agriculture and Forestry.

NIWA. 2007. The Northland Floods 28-29 March 2007. Hydrological Hazards Hindvestigation. Report National Institute for Water and Atmosphere.

NZ Herald. 2007. Avocado conference chance for reality-check on damage. In: NZ Herald. Auckland.

Risbey, J.; Kandlikar, M.; Dowlatabadi, H. 1999. Scale, context, and decision making in agricultural adaption to climate variability and change. Mitigation and Adaption Strategies for Global Change 4: 137-165.

Smit, B.; Skinner, M.W. 2002. Adaption options in agriculture to climate change: A typology. Mitigation and Adaption Strategies for Global Change 7: 85-114. Statistics NZ. 2007. Agricultural Production Census.

Walker, B.; Holling, C.S.; Carpenter, S.R.; Kinzig, A. 2004. Resilience, adaptability and transformability in social-ecological systems. Ecology and Society 9(2): 5. 